\title{
Preventive aspects and patient satisfaction with laser aided gingivectomy versus conventional method.
}

\author{
An in-vivo comparative study
}

\begin{abstract}
Aras Maruf Rauf ${ }^{(1)}$, Ara Omer Fattah ${ }^{(2)}$
Background and Objectives: Nowadays, the field of dentistry has undergone an outstanding remarkable advances in both scientific and technological aspects, dentists are obligated to synchronize the progressive demands of the patients. Gingival diseases are among the most common health problems of human being. Gingivectomy, as a surgical interference can be performed with either scalpel or soft tissue Laser The objective of this study was to evaluate the preventive extent of Diode Laser in regards to gingivectomy associated complications beside the patient's satisfaction.

Methods: This in vivo comparative study was designed to include 64 patients, divided into 2 groups of patients treated with either Laser therapy (34 Patients) or conventional method (30 Patients) of gingivectomy. The outcomes of the study plus patients' satisfaction with each procedure were analyzed using IBM SPSS V. 22 program.

Results: The mean age of the sample was $25.01+6.56$ years, more than half $(57.8 \%)$ of the sample were females. All the patients in the surgery group needed local anesthesia and periodontal pack compared to $23.5 \%$ and $0 \%$ of patients in the laser group respectively. The bleeding was significantly more severe in the first group than second group. The mean ranks of the post-operative pain scores among patients of the surgery group were significantly higher than laser group $(p<0.001)$. More than forty percent of the patients in the laser group were strongly satisfied with the procedure compared to $10 \%$ of patients in the surgery group.

Conclusions: Diode laser can be used as a preventive tool for undesired Gingivectomyassociated pain, bleeding, and needs for anaesthesia which subsequently leads to more patient satisfaction compared to conventional methods.
\end{abstract}

Keywords: Diode laser, gingivectomy, comparative study, preventive tool.

\footnotetext{
(1) College of Dentistry, University of Sulaimani, Sulaimaniyah, Iraq.

${ }^{(2)}$ College of Dentistry, University of Sulaimani, Sulaimaniyah, Iraq.

Correspondence: Dr. Aras Maruf Rauf,

Email: aras.rauf@univsul.edu.iq

Tel: 00964 (0) 7702419930
}

\section{Introduction}

Gingival enlargement, which is an inflammatory response of gingival tissue secondary to the exposure with pathogenic microorganisms especially bacteria of different species. This is a result of nonaccomplishing effective oral hygiene by the patient The enlargement could be localized or generalized. When this condition occurs and left without treatment, the condition will be more progressive and involve the periodontal tissue. ${ }^{1}$ The primary onset of this condition usually resolves with initial periodontal treatment and effective oral hygiene practices. Sometimes, more advanced treatments may be needed for a good aesthetic

appearance. $^{2}$

Gingivectomy procedures usually performed in such circumstances for recontouring the 
gingival margin. ${ }^{3}$ Gingivectomy can be performed by different methods such as scalpels, electrosurgery, chemosurgery, and laser. In the past, conventional surgery performed by a scalpel, it was the most common method of gingivectomy despite the concurrent and post-operative complications and undesired sensation. Excessive bleeding during the operation, posts-operative high level pain plus long healing time of this treatment may cause patient discomfort with conventional gingivectomy procedures. ${ }^{4-5}$ All of these factors prevent the convenience of the physician and success of operation. ${ }^{6}$ On the other hand, Gingivectomy can be performed easily with or without anesthesia using diode laser. ${ }^{6-7}$ Diode lasers can provide hemostasis, less postoperative pain and swelling reduce the infection risk, and may improve aesthetics and accelerate recovery time while soft tissue healing. ${ }^{8-10}$ The most suitable wavelength used for treatment of inflamed gingiva or hyperplasic soft tissues with a very high vascular component is near or far infrared laser. ${ }^{11}$ Diode laser is a near -infrared type laser with a wavelength ranging from $800 \mathrm{~nm}$ to $980 \mathrm{~nm}$. The laser wavelengths are selected according to each specific tissue biotype; it is always important to use the correct wavelength. diode lasers have a very gentle incision procedure in soft tissue with cutting depth ranges from 2 to $6 \mathrm{~mm}$. This type of laser has a very good surgical and hemostatic action on soft tissues following numerous soft tissue surgical procedure within the oral cavity. ${ }^{12-14}$ As Long as, a few number of articles with relatively small sized sample were found in the literature concerning gingivectomy in pediatric and teenager patients receiving orthodontic treatment and no much studies compared diode laser with conventional surgery procedure in adult patient. ${ }^{15-17}$ In the present study, $940 \mathrm{~nm}$ diode laser was compared with conventional scalpel surgery on postoperative bleeding, pain, needs for local anesthesia (LA), especially injection type and patient satisfaction.

\section{Patients and Methods}

This comparative study was carried out at Sulaimani City throughout 2 calendar years from 2016 till 2018 at two different clinics of dental specialties.

Study design. An in vivo comparative study.

Ethical consideration. This clinical trial was done in accordance with declaration of Helsinki - Ethical principles for medical research involving human subjects by World Medical Association (WMA-2013). Moreover, Ethical approval was obtained from the ethical committee of the medical colleges at University of Sulaimani. Every patient or care giver of underage patients (less than 18 years old) was informed about the clinical procedures and the purpose of the study before he/she signed on a consent form (written in his/her language). Non Smoker patients with no Systemic and/or continuous medication which induces gingival enlargement were included in the study.

Inclusion criteria. The patients were included in the study when they agreed to participate willingly, free of any systemic disease which might be contributed to the development of gingival enlargement such as Diabetes mellitus, non-smoker, and no pregnancy for female patients.

The procedure. Sixty-four patients $(27$ males, 37 females) of different age groups that ranged from 20 years up to 30 years, were treated from gingival enlargement with gingivectomy procedure at the dental clinics of both B\&R dental center and Faruk Medical City (FMC). The patients were randomly divided into two groups named: laser group (34 patients, treated with diode laser) and conventional group (30 patients, treated with the conventional surgical method), the patients of each group was treated by a single operator as a matter of standardization.

All the patients received oral hygiene instructions, motivation, and a thorough gingival scaling and polishing in advance to the operations. In the conventional surgical method group, topical anesthetic was applied before surgery followed by local infiltration anesthesia (2\% lignocaine with 1: 80,000 epinephrine) to achieve deep anesthesia for patients. The 
conventional surgical method performed by a standard surgical scalpel (No.15) with scalloped external bevel incision and then, a sulcular incision was performed with an Orban knife. Following excision of the enlarged tissue with curettes, gingivoplasty was performed by Kirkland knife for all patients. Finally, the operated gingiva was covered with periodontal pack.

For the laser group patients, LA was achieved by only topical gel of Lidocaine $5 \%$ unless the patient asked for deep anesthesia in case of intolerable pain during the operation. The patients were treated for 30 second per tooth by a $940 \mathrm{~nm}$ diode laser (EpicX, Biolase, California, USA) with a $400 \mu \mathrm{m}$ fiber at $1 \mathrm{~W}$ power, the laser tip moved horizontally with a continuous laser beam, the gingival tissue was removed and shaped for gingivoplasty. No periodontal packs were used.

Acetaminophen tablets $(500 \mathrm{mg})$ were prescribed for the patients of both groups for analgesia and the patients were advised to take a tablet as needed post-operatively.

Bleeding and pain scoring. A single operator recorded the severity of bleeding at the day of operation in addition to the first and third post-operative days using scores adopted by other researcher, ${ }^{18}$ bleeding was assessed according to the following grades: 1. None, 2. Self-limiting, 3. Requiring light pressure, 4. Requiring coagulation, 5. Requiring ligation. Pain scores were recorded during the procedure and at the first post-operative day till seventh day.

The patients were asked to rate the degree of pain during their usual day life activities, especially eating or speech, on a $10 \mathrm{~cm}$ horizontal visual analog scale (VAS) by placing a vertical mark to assess position between the two endpoints. The left end point was nominated as "no pain," and the right end point was nominated as "worst pain possible."

Finally, the patients of both the groups were asked to declare their satisfaction rate with the procedure of treatment for $(0$ : Not satisfied, 1: Satisfied, 2: Strongly satisfied).

Statistical analysis. Data were analyzed using the Statistical Package for Social Sciences (SPSS, version 22). Chi square test of association was used to compare proportions. Fisher's exact test was used when the expected count of more than $20 \%$ of the cells of the table was less than 5. Mann Whitney test (a non-parametric test) was used to compare the mean ranks of the two study groups. A $p$ value of $\leq$ 0.05 was considered statistically significant.

\section{Results}

Sixty-four patients underwent gingivectomy, laser was used for 34 patients, and scalpel surgery for the rest 30 patients. The mean age \pm SD of the sample were $25.01 \pm 6.56$ years, ranging from 18 to 44 years. The median was 23 years. Table 1 shows that $43.3 \%$ of patients in the surgery group aged $\geq 30$ years, compared with $0 \%$ in the laser group ( $p<0.001)$. More than half $(57.8 \%)$ of the sample were females, but there was no significant difference between the two groups regarding the gender distribution $(p=0.401)$ this result can be seen in table 1 .

All the patients in the conventional surgery group needed local anesthesia compared with $23.5 \%$ of patients in the laser group $(p<0.001)$ as presented in Table 2. All the patients in the surgery group needed periodontal pack while none of the patients in the laser group needed such a pack $(p<0.001)$. The table shows that $41.2 \%$ of the patients in the laser group were strongly satisfied with the outcome compared with $10 \%$ of patients in the surgery group $(\mathrm{p}=0.001)$. All the patients in the conventional surgery group developed severe bleeding during surgery compared with $0 \%$ in the laser group $(\mathrm{p}=0.001)$. Regarding the postoperative bleeding, 1 and 3 days after surgery, the table shows that, in general, the bleeding was significantly more severe in the surgery group than the laser group $(\mathrm{p}<0.001)$.

It is evident in Table 3 that, all the medians of pain scores of the first seven days after surgery among patients of the surgery group were higher than the medians of the laser group. The mean ranks of the pain scores among patients of the surgery group were significantly higher than the mean ranks of the laser group $(\mathrm{p}<0.001)$. 
Table 1: Age and gender distribution.

\begin{tabular}{|c|c|c|c|c|c|c|}
\hline \multirow{2}{*}{ Age groups } & \multicolumn{2}{|c|}{ Laser } & \multicolumn{2}{|c|}{ Conventional Surgical method } & \multicolumn{2}{|c|}{ Total } \\
\hline & No. & (\%) & No. & (\%) & No. & $(\%)$ \\
\hline$<20$ & 10 & (29.4) & 3 & $(10.0)$ & 13 & (20.3) \\
\hline $20-24$ & 18 & (52.9) & 5 & $(16.7)$ & 23 & (35.9) \\
\hline $25-29$ & 6 & (17.6) & 9 & $(30.0)$ & 15 & (23.4) \\
\hline$\geq \mathbf{3 0}$ & 0 & $(0.0)$ & 13 & (43.3) & 13 & $(20.3)$ \\
\hline Gender & & & & & & \\
\hline Male & 16 & $(47.1)$ & 11 & $(36.7)$ & 27 & $(42.2)$ \\
\hline Female & 18 & (52.9) & 19 & $(63.3)$ & 37 & $(57.8)$ \\
\hline Total & 34 & $(100.0)$ & 30 & $(100.0)$ & 64 & (100.0) \\
\hline
\end{tabular}

Table 2: Needs of local anesthesia, Periodontal pack. patients' satisfaction, and incidence of complications in the two study groups.

\begin{tabular}{|c|c|c|c|c|c|c|c|c|}
\hline & \multicolumn{2}{|c|}{ Laser group patients } & \multicolumn{2}{|c|}{$\begin{array}{c}\text { Conventional surgi- } \\
\text { cal method }\end{array}$} & \multicolumn{2}{|c|}{ Total } & \multirow{2}{*}{ P Value } \\
\hline & & No. & (\%) & No. & (\%) & No. & (\%) & \\
\hline \multirow{2}{*}{$\begin{array}{l}\text { Need for local } \\
\text { anesthesia }\end{array}$} & No & 26 & $(76.5)$ & 0 & $(0.0)$ & 26 & $(40.6)$ & \multirow[b]{2}{*}{$<0.001$} \\
\hline & Yes & 8 & $(23.5)$ & 30 & $(100.0)$ & 38 & (59.4) & \\
\hline \multirow{2}{*}{$\begin{array}{l}\text { Need for perio- } \\
\text { dontal pack }\end{array}$} & No & 34 & $(100.0)$ & 0 & $(0.0)$ & 34 & (53.1) & \multirow[b]{2}{*}{$<0.001$} \\
\hline & Yes & 0 & $(0.0)$ & 30 & $(100.0)$ & 30 & $(46.9)$ & \\
\hline \multirow{3}{*}{$\begin{array}{c}\text { Patient satisfac- } \\
\text { tion }\end{array}$} & $\begin{array}{l}\text { Not satis- } \\
\text { fied }\end{array}$ & 0 & $(0.0)$ & 6 & $(20.0)$ & 6 & $(9.4)$ & \multirow{3}{*}{$0.001 *$} \\
\hline & Satisfied & 20 & $(58.8$ & 21 & (70.0) & 41 & (64.1) & \\
\hline & $\begin{array}{l}\text { Strongly } \\
\text { satisfied }\end{array}$ & 14 & $(41.2)$ & 3 & $(10.0)$ & 17 & $(26.6)$ & \\
\hline \multirow[b]{2}{*}{$\begin{array}{l}\text { Bleeding during } \\
\text { surgery }\end{array}$} & Self-limiting & 34 & $(100.0)$ & 0 & $(0.0$ & 34 & (53.1) & \multirow[b]{2}{*}{$<0.001$} \\
\hline & $\begin{array}{l}\text { Require } \\
\text { light pres- } \\
\text { sure }\end{array}$ & 0 & (0.0) & 30 & $(100.0)$ & 30 & (46.9) & \\
\hline \multirow{3}{*}{$\begin{array}{l}\text { Post-operative } \\
\text { bleeding } 1^{\text {st }} \text { day }\end{array}$} & Self-limiting & 34 & $(100.0)$ & 0 & $(0.0)$ & 34 & (53.1) & \multirow{3}{*}{$<0.001 *$} \\
\hline & $\begin{array}{l}\text { Require } \\
\text { light pres- } \\
\text { sure }\end{array}$ & 0 & $(0.0)$ & 27 & (90.0) & 27 & (42.2) & \\
\hline & $\begin{array}{l}\text { Requiring } \\
\text { coagulation }\end{array}$ & 0 & $(0.0)$ & 3 & (10.0) & 3 & $(4.7)$ & \\
\hline \multirow{3}{*}{$\begin{array}{c}\text { Post-operative } \\
\text { bleeding after } 3 \\
\text { days }\end{array}$} & Self-limiting & 34 & $(100.0)$ & 14 & (46.7) & 48 & $(75.0$ & \multirow{3}{*}{$<0.001$} \\
\hline & $\begin{array}{c}\text { Require } \\
\text { light pres- } \\
\text { sure } \\
\end{array}$ & 0 & $(0.0)$ & 16 & (53.3) & 16 & $(25.0)$ & \\
\hline & Total & 34 & $(100.0$ & 30 & (100.0) & 64 & (100.0) & \\
\hline
\end{tabular}

*By Fisher's exact test. 
Table 3. Mean ranks of the pain scores of the two study groups.

\begin{tabular}{|c|c|c|c|c|c|}
\hline \multirow{2}{*}{$\begin{array}{c}\text { Days after the } \\
\text { operation }\end{array}$} & \multicolumn{2}{|c|}{ Laser pain scores } & \multicolumn{2}{c|}{ Surgery pain scores } & \multirow{2}{*}{ P Value } \\
\cline { 2 - 6 } & Mean rank & Median & Mean rank & Median & $<0.001$ \\
\hline Day 1 & 18.12 & 3.0 & 48.80 & 6.0 & $<0.001$ \\
\hline Day 2 & 19.26 & 2.0 & 47.50 & 3.5 & $<0.001$ \\
\hline Day 3 & 18.74 & 1.0 & 48.10 & 3.0 & $<0.001$ \\
\hline Day 4 & 18.38 & 0.0 & 48.50 & 2.0 & $<0.001$ \\
\hline Day 5 & 17.50 & 0.0 & 49.50 & 2.0 & $<0.001$ \\
\hline day 6 & 17.50 & 0.0 & 49.50 & 1.0 & $<0.001$ \\
\hline Day 7 & 19.50 & 0.0 & 47.23 & 1.0 & $<$ \\
\hline
\end{tabular}

*By Mann Whitney test.

\section{Discussions}

In the present study, Diode laser surgery been compared to the conventional surgical method with scalpel in regards to necessity to infiltration type of LA, periodontal dressing with a pack, post-operative pain, bleeding in 3 different occasions, and patients' satisfaction with each procedure. Sixty-four patients underwent gingivectomy, laser was used for 34 cases, and surgery for the rest of the patients (30 patients). About one quarter of the laser group patients asked for LA while, all the patients in the other group anesthetized with $2 \%$ lignocaine, which explains that, diode laser initiate minimum pain and harmful effect during surgical procedures of oral soft. ${ }^{19-20}$ The bleeding rate within the diode laser group were found at the minimum rate in contrast to the second group, these results were an agreement with other studies. ${ }^{15,18,22}$ Reduced bleeding during surgery, rapid postoperative hemostasis and clear vision of the surgical field were observed in the laser group, which showed compatibility with other study. ${ }^{19,23-24}$ The irradiated tissue constricts against the proximal vasculature and the shrinkage of the collagen in the walls of blood vessels will improve hemostasis. Laser damage to erythrocytes enhanced aggregation of platelets which encourage intraluminal thrombosis and further decrease in the blood loss and this explains why the laser group had minimal blood loss in comparison to the scalpel group. ${ }^{25}$ Generally, it was noticed that, conventional surgical approach has caused some problems like: surgical trauma, bleeding during surgery, postoperative pain and swelling, these problems can handle more easily with lasers. $^{26}$ No extensive bleeding and tissue damage at the operated sites of the laser group made the application of periodontal pack unnecessary. There was a significant difference between the two groups in regard to post-operative bleeding at two subsequent occasions ( $1^{\text {st }}$ day and $3^{\text {rd }}$ day after the operation) when the laser surgery showed less bleeding, this can be clarified by the fact that, diode lasers are highly absorbed by hemoglobin and melanin, this allow precise cutting of soft tissue with excellent homeostasis and deep penetration which consequently reduce the operation time and

postoperative bleeding without the need to surgical pack or suture. ${ }^{8,14,17,23}$ It has the ability to be absorbed by gingival tissue rather than the adjacent structures which makes this device of choice for gingival surgery. The interaction of laser wavelength and energy density with tissues at the tip of fiberoptic contact delivery system allows simultaneous cutting and coagulation of tissue. ${ }^{27-29}$

The recorded postoperative pain scores were significantly more in the patients treated with diode laser as compared to surgical procedure, no patients asked for analgesia except for some surgical method patients within the next the days of post-operative treatment. The pain 
was controlled with Acetaminophen tablets with the dose of $500 \mathrm{mg}$, as required with no more than 3 times a day after treatment. The decontamination ability of lasers allows the surgeon to work in almost sterilized surgical field that reduced the possibility of postoperative infection and subsequently reduces pain sensation. ${ }^{30}$

All the patients were satisfied with Laser surgery, on the other hand, not all the patients were happy with the conventional type of gingivectomy with a significant difference between the two groups, this proves that, laser aided operations are less frightening and more acceptable by the patients, this result was in accordance with other studies. ${ }^{31}$

The subjective quality of pain threshold may be limitation of this clinical study, for this reason, VAS as a reliable and reproducible tool was used for patients.

\section{Conclusion}

It was concluded from the results of the present study that, Undesired Gingivectomy -associated pain, bleeding, and needs for anaesthesia that associated with conventional procedure can be diminished to the lowest level with soft tissue laser and subsequently leads to more patient satisfaction, so diode lasers can be used as a suitable preventive tool for most of the complications, discomforts, and difficulties that associated with conventional method of gingivectomy procedure.

\section{Conflict of interest}

The authors reported no conflict of interests.

\section{References}

1. Carranza FA, Hogan EL. Gingival enlargement. Newman MG, Takei HH and Carranza FA, editors. Carranza's clinical periodontology. Saunders; 2002. p. 279-96.

2. Seki K, Sato S, Asano Y, Akutagawa H, Ito K. Improved pathologic teeth migration following gingivectomy in a case of idiopathic gingival fibromatosis. Quintessence Int 2010; 41:543-5.

3. Foley TF, Sandhu HS, Athanasopoulos C. Esthetic periodontal considerations in orthodontic treatment--the management of excessive gingival display. J Can Dent Assoc 2003; 69: 368-72.

4. Parker S. Low-level laser use in dentistry. Br Dent J 2007; 202:131-8.
5. de Santana-Santos T, de Souza-Santos A, MartinsFilho PR, da Silva LC, de Oliveira ESED, Gomes AC. Prediction of postoperative facial swelling, pain and trismus following third molar surgery based on preoperative variables. Med Oral Patol Oral Cir Bucal 2013;18: e65-70.

6. Ozcelik O, Cenk Haytac M, Kunin A, Seydaoglu G. Improved wound healing by low-level laser irradiation after gingivectomy operations: a controlled clinical pilot study. J Clin Periodontol 2008; 35:250-4.

7. Sarver DM. Use of the $810 \mathrm{~nm}$ diode laser: soft tissue management and orthodontic applications of innovative technology. Pract Proced Aesthet Dent 2006; 18: suppl 7-13.

8. Fornaini C, Rocca JP, Bertrand MF, Merigo E, Nammour S, Vescovi P. Nd:YAG and diode laser in the surgical management of soft tissues related to orthodontic treatment. Photomed Laser Surg 2007; 25:381-92.

9. Gontijo I, Navarro RS, Haypek P, Ciamponi AL, Haddad AE. The applications of diode and Er:YAG lasers in labial frenectomy in infant patients. J Dent Child (Chic) 2005; 72:10-5.

10. Vescovi $P$, Corcione $L$, Meleti $M$, Merigo E, Fornaini $C$, Manfredi $M$, et al. Nd:YAG laser versus traditional scalpel. A preliminary histological analysis of specimens from the human oral mucosa. Lasers Med Sci 2010; 25:685-91

11. Coluzzi DJ. Fundamentals of dental lasers: science and instruments. Dent Clin North Am 2004 48:751- 70.

12. Luomanen M. Experience with a carbon dioxide laser for removal of benign oral soft-tissue lesions. Proc Finn Dent Soc 1992; 88:49-

13. Pirnat S. Versatility of an $810 \mathrm{~nm}$ diode laser in dentistry: An overview. J Laser Health Acad 2007; 4:1-9.

14. Genovese MD, Olivi G. Use of laser technology in orthodontics: hard and soft tissue laser treatments. Eur J Paediatr Dent 2010; 11:44-8.

15. Ize-Iyamu IN, Saheeb BD, Edetanlen BE. Comparing the $810 \mathrm{~nm}$ diode laser with conventional surgery in orthodontic soft tissue procedures. Ghana Med J 2013; 47:107-11.

16. Shankar BS, T R, S NM, Reddy PS, Saritha G, Reddy JM. Chronic inflammatory gingival overgrowths: laser gingivectomy \& gingivoplasty. J Int Oral Health 2013; 5:83-7

17. Sobouti F, Rakhshan V, Chiniforush N, Khatami M. Effects of laser-assisted cosmetic smile lift gingivectomy on postoperative bleeding and pain in fixed orthodontic patients: a controlled clinical trial. Prog Orthod 2014; 15:66.

18. Kumar, P., Rattan, V. and Rai, S., 2015. Comparative evaluation of healing after gingivectomy 
with electrocautery and laser. Journal of oral biology and craniofacial research, 5(2), pp.6974.

19. Kravitz ND, Kusnoto B. Soft-tissue lasers in orthodontics: an overview. Am J Orthod Dentofacial Orthop 2008; 133: S110-4.

20. Kafas $P$, Stavrianos $C$, Jerjes $W$, Upile T, Vourvachis $M$, Theodoridis $M$, et al. Upper-lip laser frenectomy without infiltrated anaesthesia in a paediatric patient: a case report. Cases J 2009;2: 7138

21. Webert K, Cook RJ, Sigouin CS, Rebulla P, Heddle NM. The risk of bleeding in thrombocytopenic patients with acute myeloid leukemia. Haematologica 2006; 91:1530-7.

22. Kersten $P$, White PJ, Tennant $A$. Is the pain visual analogue scale linear and responsive to change? An exploration using Rasch analysis. PLoS One 2014; 9: e99485

23. Amaral, M.B.F., de Avila, J.M.S., Abreu, M.H.G. and Mesquita, R.A., 2015. Diode laser surgery versus scalpel surgery in the treatment of fibrous hyperplasia: a randomized clinical trial. International journal of oral and maxillofacial surgery, 44(11), pp.1383-1389

24. Asnaashari, M., Azari-Marhabi, S., Alirezaei, S. and Asnaashari, N., 2013. Clinical Application of 810nm Diode Laser to Remove Gingival Hyperplasic Lesion. Journal of lasers in medical sciences, 4(2), p.96.
25. Aoki, A., Watanabe, H., Namiki, N., Takiguchi, T., Miyazawa, Y., Suzuki, M., Hasegawa, K. and Ishikawa, I., 2003, May. Periodontal soft tissue management with a high pulse rate Er: YAG laser. In International Congress Series (Vol. 1248, pp. 367-369). Elsevier.

26. Grossi GB, Maiorana C, Garramone RA, Borgonovo A, Creminelli L, Santoro F. Assessing $r$

postoperative discomfort after third molar surgery: a prospective study. J Oral Maxillofac Surg 2007; 65:901-17.

27. Stubinger S., Saldamli B. Soft tissue surgery with the diode laser- theoretical and clinical aspects. Schweiz Monatsschr Zahnmed. 2006; 116:812-820.

28. Janda P., Sroka R. Comparison of thermal effects induced by contact application of fiber guided laser systems. Lasers Surg Med. 2003; 33:93101

29. Goharkhay K., Moritz A. Effects on oral soft tissue produced by a diode laser in vitro. Lasers Surg Med. 1999; 25:401-406.

30. Fisher, S.E. and Frame, J.W., 1984. The effects of the carbon dioxide surgical laser on oral tissues. British journal of oral and maxillofacial surgery, 22(6), pp.414-425.

31. Öncü $E$, Erbeyoğlu AA, Alan R. Comparison of gingivectomy procedures for patient satisfaction: Conventional and diode laser surgery. Selcuk Dent J, 2017; 4: 6-9. 